EUROPEAN CENTRAL BANK

WORKING PAPER SERIES

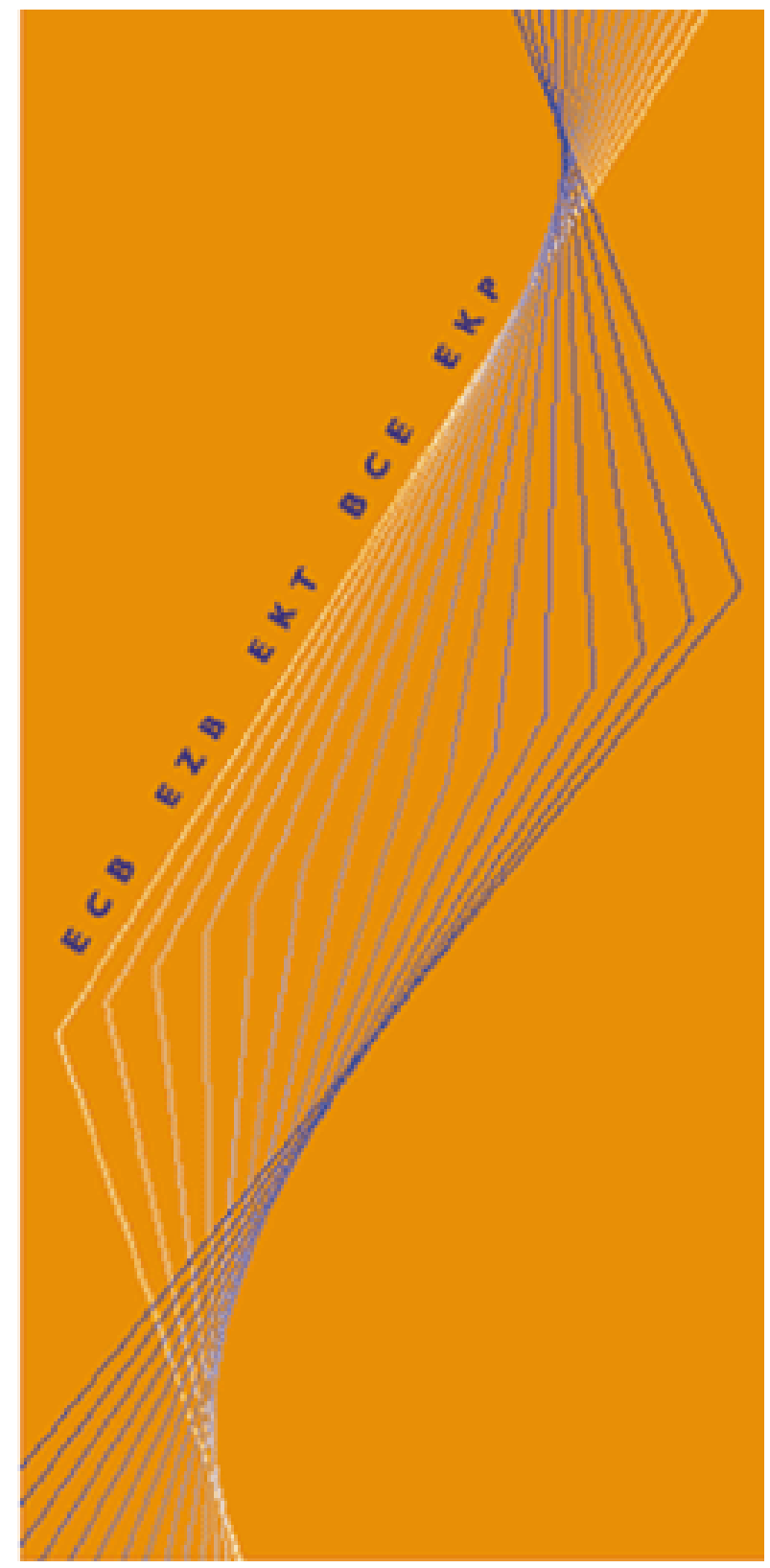

WORKING PAPER NO. 2 I 7

THE ROLE OF PRODUCT MARKET REGULATIONS IN

THE PROCESS OF STRUCTURAL CHANGE BY JULIÁN MESSINA

March 2003 


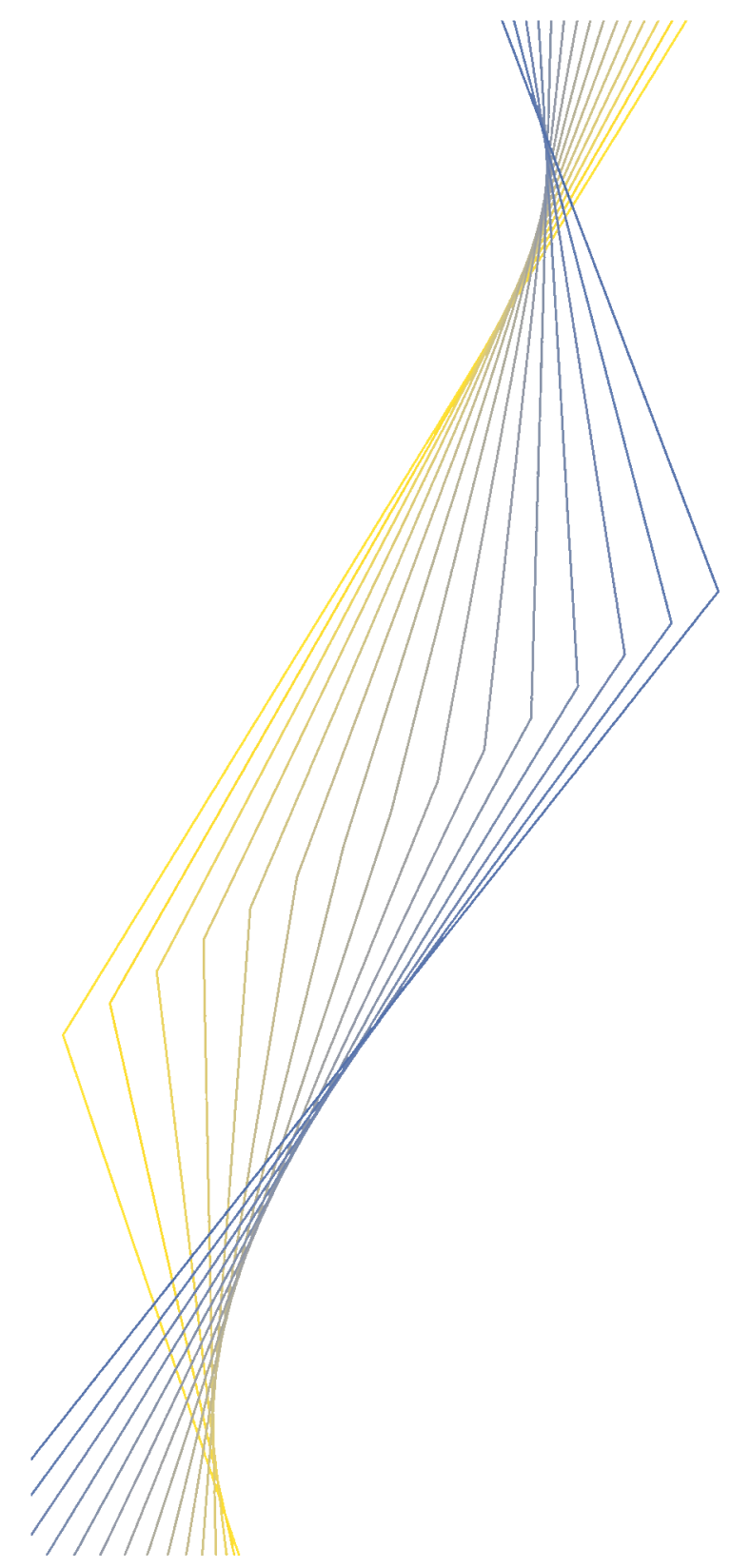

WORKING PAPER NO. 217

THE ROLE OF PRODUCT

MARKET REGULATIONS IN

THE PROCESS OF

STRUCTURAL CHANGE'

BY JULIÁN MESSINA²

\section{March 2003}

I I am particularly indebted to Giuseppe Bertola, for lengthy discussions and guidance. This paper also benefited of comments from Andrea Ichino, Anna Sanz de Galdeano, Martin Zagler and an anonymous referee of the ECB Working paper series, which are gratefully acknowledged. Seminar participants at the ECB, CSEF, IUE and Frankfurt University also provided useful comments. I finally want to thank Stephen Broadberry for generously providing me with the US productivity data. All errors are the author's responsibility. The opinions expressed herein are those of the author and do not necessarily represent those of the European Central Bank. This paper can be downloaded without charge from http:I/www.ecb. int or from the Social Science Research Network electronic library at: $h$ ttp://ssrn.com/abstract_id $=x x x x x x$ 
(C) European Central Bank, 2003

$\begin{array}{ll}\text { Address } & \text { Kaiserstrasse 29 } \\ & \text { D-603 I I Frankfurt am Main } \\ & \text { Germany } \\ & \text { Postfach } 1603 \text { I9 } \\ \text { Postal address } & \text { Germany Frankfurt am Main } \\ & +4969 \text { I344 } 0 \\ \text { Telephone } & \text { http://www.ecb.int } \\ \text { Internet } & +4969 \text { I344 } 6000 \\ \text { Fax } & 41 \text { I I44 ecb d } \\ \text { Telex } & \end{array}$

All rights reserved.

Reproduction for educational and non-commercial purposes is permitted provided that the source is acknowledged. The views expressed in this paper do not necessarily reflect those of the European Central Bank.

ISSN I56I-08I0 (print)

ISSN I725-2806 (online) 


\section{Contents}

$\begin{array}{ll}\text { Abstract } & 4\end{array}$

Non-technical summary $\quad 5$

$\begin{array}{lll}\text { I Introduction } & 7\end{array}$

$2 \quad$ Structural change and product market regulations 8

3 The model 12

3.I Labor demand $\quad 12$

3.2 Households 13

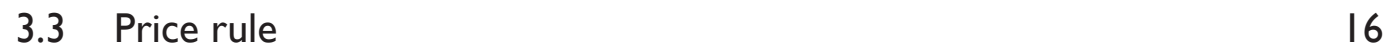

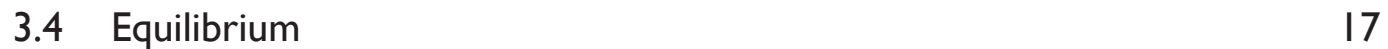

$\begin{array}{lll}3.5 & \text { Parameterization } & 18\end{array}$

$4 \quad$ Long-run.The free entry case 19

$5 \quad$ Introducing product market regulations 21

5.I Discussion. Taste for variety as a public good 25

$\begin{array}{llr}6 & \text { Conclusions } & 27\end{array}$

$\begin{array}{lr}\text { References } & 29\end{array}$

European Central Bank working paper series $\quad 32$ 


\begin{abstract}
The sectoral allocation of labor differs considerably across developed economies, even in the presence of similar patterns of structural change. A general equilibrium model that captures the stylized facts of structural change is presented. In this framework, product market regulations raise barriers to entry that hinder the development of sectors with income elastic demand such as service industries. Thus, the paper suggests that differences in the regulations of product markets might help explaining cross-country differences in the sectoral allocation of employment. Crosscountry evidence discussed in the paper shows that this proposition is supported by the data for a sample of OECD countries. Additionally, the model shows that higher service prices and rents in regulated economies reduce labor supply, providing a rationale for the negative association between product market regulations and the employment rate previously found in the literature.
\end{abstract}

JEL Classification: O11, O41, L5.

Keywords: Unbalanced Growth, Product Market Regulations. 


\section{Non-technical Summary}

Service industries have absorbed a continuously increasing share of the labor force of developed economies during the last century, while agricultural activities have lost weight dramatically. This process of structural change has led researchers to establish the positive (negative) association between the service (agricultural) employment share and GDP per capita as a stylized fact of modern economic growth. However, remarkable differences in the sectoral distribution of employment can still be observed across countries at a similar stage of development. For instance, some European countries such as Austria, Italy and Germany have service employment shares barely exceeding 60 per cent in the second half of the 1990s, 10 percentage points lower than in the Netherlands, Australia or Canada.

The traditional forces regarded as engines of structural change -differences in the income elasticity of demand of different goods and sectoral productivity growth differentialsdo not seem to be able to account for divergent sectoral structures across countries with similar technology and tastes. On the contrary, empirical evidence discussed in the paper suggests that product market regulations might help in explaining the underdevelopment of service industries in tightly regulated countries.

Considering this evidence, the paper proposes a general equilibrium model where product market regulations restrict entry at the firm level, to analyze the interactions between these institutions and the engines of structural change in shaping macroeconomic outcomes. In the economy described in the paper, households consume goods provided by three different sectors -agriculture, manufacturing and services- according to non-homothetic preferences. It is assumed that the income elasticity of demand for services is larger than for manufacturing and agricultural goods, establishing a hierarchy of tastes that explains a progressive terciarization of the economy as income grows. Income per capita evolves according to an exogenous process of productivity growth. Within the model, the rate of productivity growth in service industries lags behind the manufacturing and agriculture productivity growth rates constituting the second engine of structural change. Finally, product markets are monopolistically competitive, and regulations in these markets raise economy-wide barriers to entry that obstruct the creation of new firms in all sectors.

The model captures several stylized facts of structural change: (1) an increase (reduction) in the services (agricultural) sectoral employment share along the growth process; (2) a similar pattern with regard to nominal GDP shares; (3) a less marked increase in the real GDP share of the service sector; and (4) a continuous decline of the employment rate associated with the secular fall of employment engaged in agricultural activities. 
Entry barriers reduce competitive pressure, resulting in higher prices for all goods if variety is sufficiently valued by individuals. Consequently, product market regulations reduce real income and the demand of all goods and services, being this effect more than proportional in those sectors with income elastic demand such as service industries. Thus, this paper shows that economy-wide barriers to entry have asymmetric effects on the sectoral structure of an economy characterized by structural change, resulting in a reduction of the employment share engaged in the production of services. Sensitivity analysis shows that this result is robust with respect to different degrees of social desire for variety as long as product market regulations are welfare decreasing.

Non-homotheticity of preferences implies that each household is endowed with a certain amount of services that can be interpreted as home production. In the presence of product market regulations, the market price of services increase raising the relative value of producing goods at home, which together with the higher rents in the economy triggers a reduction of labor supply. This constitutes an additional income effect that further reduces the demand for services and the service employment share. Moreover, the reduction of labor supply results in a fall of the aggregate employment rate in regulated economies. This last finding is consistent with the negative association between product market regulations and the employment rate previously found in the literature. 


\section{Introduction}

Service industries have absorbed a continuously increasing share of the labor force during the last century in developed countries, while agricultural activities have lost weight dramatically. This process of structural change has led researchers to establish the positive (negative) association between the service (agricultural) employment share and GDP per capita as a stylized fact of modern economic growth. ${ }^{1}$ However, remarkable differences in the sectoral distribution of employment can still be observed across countries at a similar stage of development. For instance, some European countries such as Austria, Italy and Germany have service employment shares barely exceeding 60 per cent in the second half of the 1990s, 10 percentage points lower than in the Netherlands, Australia or Canada.

Echevarria (1997) and Kongsamut, Rebelo and Xie (2001) develop general equilibrium models consistent with the long-run patterns of structural change. These papers rely on demand (non-homothetic preferences) and supply (differences in the rate of productivity growth across sectors) forces to explain the long-run patterns in the sectoral allocation of resources. This paper considers these two forces as engines of sectoral reallocation, but focuses on their interaction with regulations that raise barriers to entry in explaining persistent cross-country differences in the sectoral structure.

Economy-wide product market regulations such as screening procedures and taxrelated requirements for start-ups, and sectoral regulations such as zoning laws or restrictions on shop opening hours constitute barriers to entry for entrepreneurs. Recent studies focus on the effects of product market regulations in labor market outcomes. At the cross-country level, the stringency of entry regulations appears negatively associated with employment rates (Nicoletti et al., 2001) and entrepreneurial activity (Fonseca et al., 2001) across OECD countries. At the sectoral level, Bertrand and Kramarz (2002) find that entry regulation hinders job creation in the French retail sector.

The model described herein captures the long-term patterns of structural change: (1) an increase (reduction) in the services (agricultural) sectoral employment share along the growth process; (2) a similar pattern with regard to nominal GDP shares; (3) a less marked increase in the real GDP share of the service sector; (4) a continuous decline of the employment rate associated with the secular fall of employment engaged in agricultural activities.

In the presence of economy-wide product market regulations, the market price of services and rents in the economy increase, triggering a reduction of labor supply. This

\footnotetext{
${ }^{1}$ Clark (1957) and Kuznets (1966) study the relationship between sectoral structure and economic growth. For a recent review of the empirical regularities in the growth of service employment see OECD (2000)
} 
provides a rationale for the negative association between product market regulations and the employment rate previously found in the literature, and is also consistent with the gap in marketization of services activities between the US and European economies found in Freeman and Schettkat (2002). Accordingly, European households would respond to more stringent regulations in product markets substituting the purchase of services in the market (e.g. child care, home repairs and leisure activities) by home production, while the Americans, facing lower service prices would supply more hours of work purchasing equivalent services in the market.

The simulations show that economy-wide regulatory barriers to entry obstruct the natural pattern of structural change, hindering the development of those sectors whose demand is income elastic. Thus, countries with more stringent product market regulations are expected to have a relatively underdeveloped service sector. This is consistent with evidence presented in the paper and further discussed in Messina (2002), which find a robust association between different indicators of product market regulations and the service employment share across OECD countries.

The paper is organized as follows. The next section discusses the cross-country patterns in the sectoral allocation of labor and presents some evidence on the role of product market regulations in the sectoral allocation of employment. In Section 3, the model of structural change is outlined. Section 4 presents the main results of the free entry version of the model and Section 5 discusses the effects of the interactions between product market regulations and the forces of structural change in shaping employment patterns. Section 6 concludes.

\section{Structural Change and Product Market Regulations}

The first panel of Figure 1 shows the distribution of the US employment shares in the three main sectors of the economy (agriculture, manufacturing and services) over the last 130 years. It shows a progressive fall in the agricultural share (from $47 \%$ in 1870 to $2 \%$ in 1996) that goes together with a continuous increase of service employment (from $26 \%$ to $70 \%$ in the same period).

This pattern of structural change is not a peculiarity of the US, but rather, a common feature across OECD countries. This is illustrated in panels 2 and 3 of Figure 1, which show a positive (negative) cross-sectional correlation between GDP per capita and the service (agriculture) employment share in the 1990s. However, these cross-plots also show important disparities in the snapshot distribution of employment across similar countries. For instance, Italy, Austria, Germany and Japan are relatively underdeveloped in terms of service employment with respect to countries like the Netherlands, Australia or Canada, while all of them lie in a similar income per capita range. 

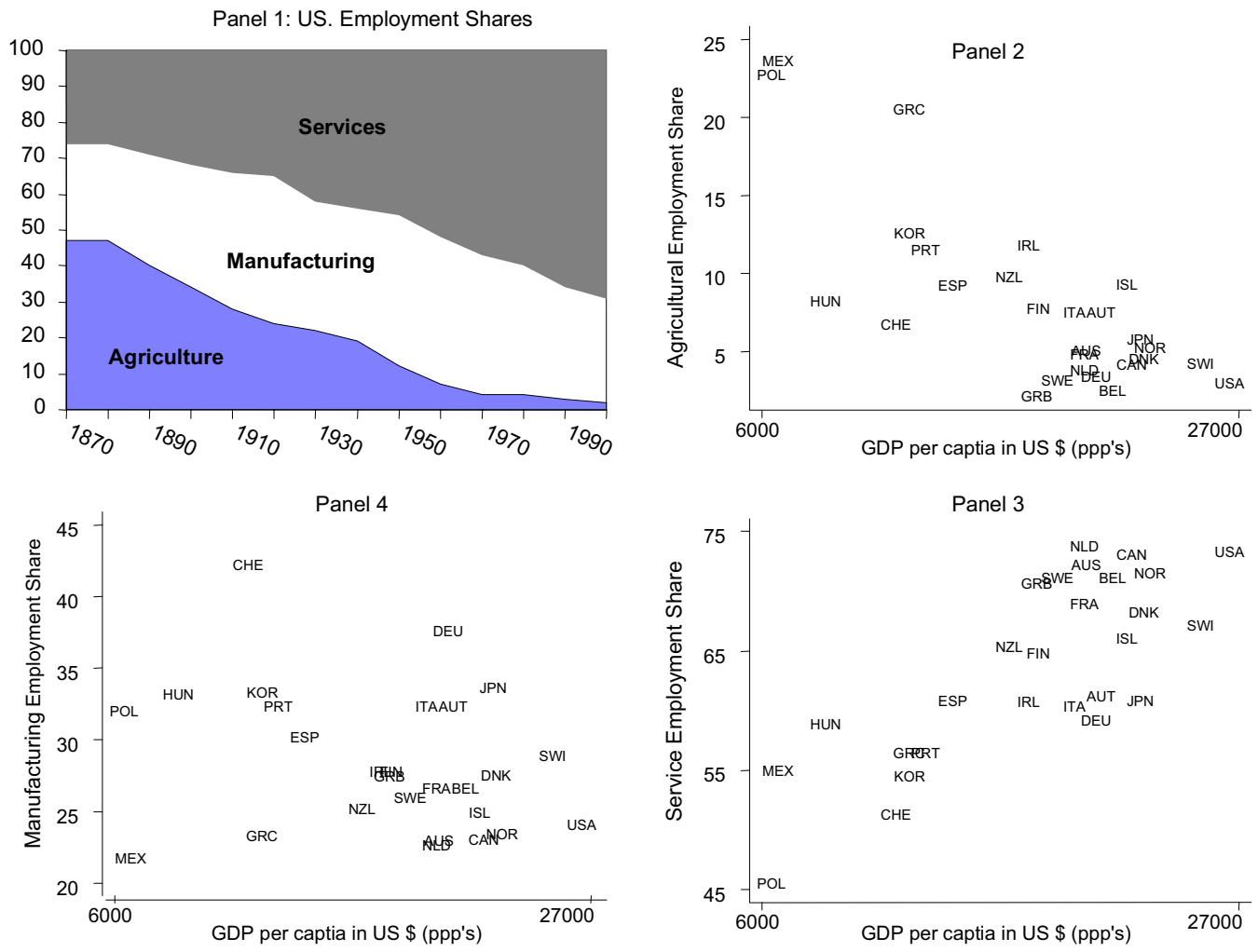

Figure 1: Structural Change and Sectoral Allocation of Employment.

Two main forces lie behind the process of structural change: (1) a hierarchy in consumer tastes and (2) differences in the rate of growth of technical change between sectors. $^{2}$

The first is associated with Engel's law, that is, with differences in income elasticities of demand for different goods. The Engel's law predicts a progressive fall in the demand for agricultural products as income per capita raises due to a saturation level in agricultural consumption. Clark (1957) argues that a similar argument applies to service demand, which benefits from a saturation in the consumption of manufacturing goods once a certain level of development is reached. Empirical evidence on the income elastic-

\footnotetext{
${ }^{2}$ There are other forces which to some extent will alter the sectoral structure of the economy along the growth process. Among them, the outsourcing of ancillary activities to specialized service providers is becoming common practice in the manufacturing sector. Although the rationales and consequences of outsourcing are beyond the scope of this paper, it should be noted that in the process of externalization barriers to entry are likely to be important, since more stringent regulatory and administrative barriers might obstruct the creation of the flexible producer service firms that are at the core of the outsourcing process.
} 
ity of demand for agricultural products clearly suggests that saturation levels have been surpassed in all OECD countries. Regarding the service sector, the evidence is less clearcut, with estimates yielding income elasticities either equal to one (Falvey and Gemmell, 1996) or slightly larger than 1 (Bergstrand, 1991). However, problems of measurement cast serious doubts on the accuracy of service output data (Gordon, 1996). If output in some service industries such as retail, wholesale trade, finance, real estate or social services is systematically mis-measured (Griliches, 1994), then estimates of the income elasticity of demand for services would be downward biased.
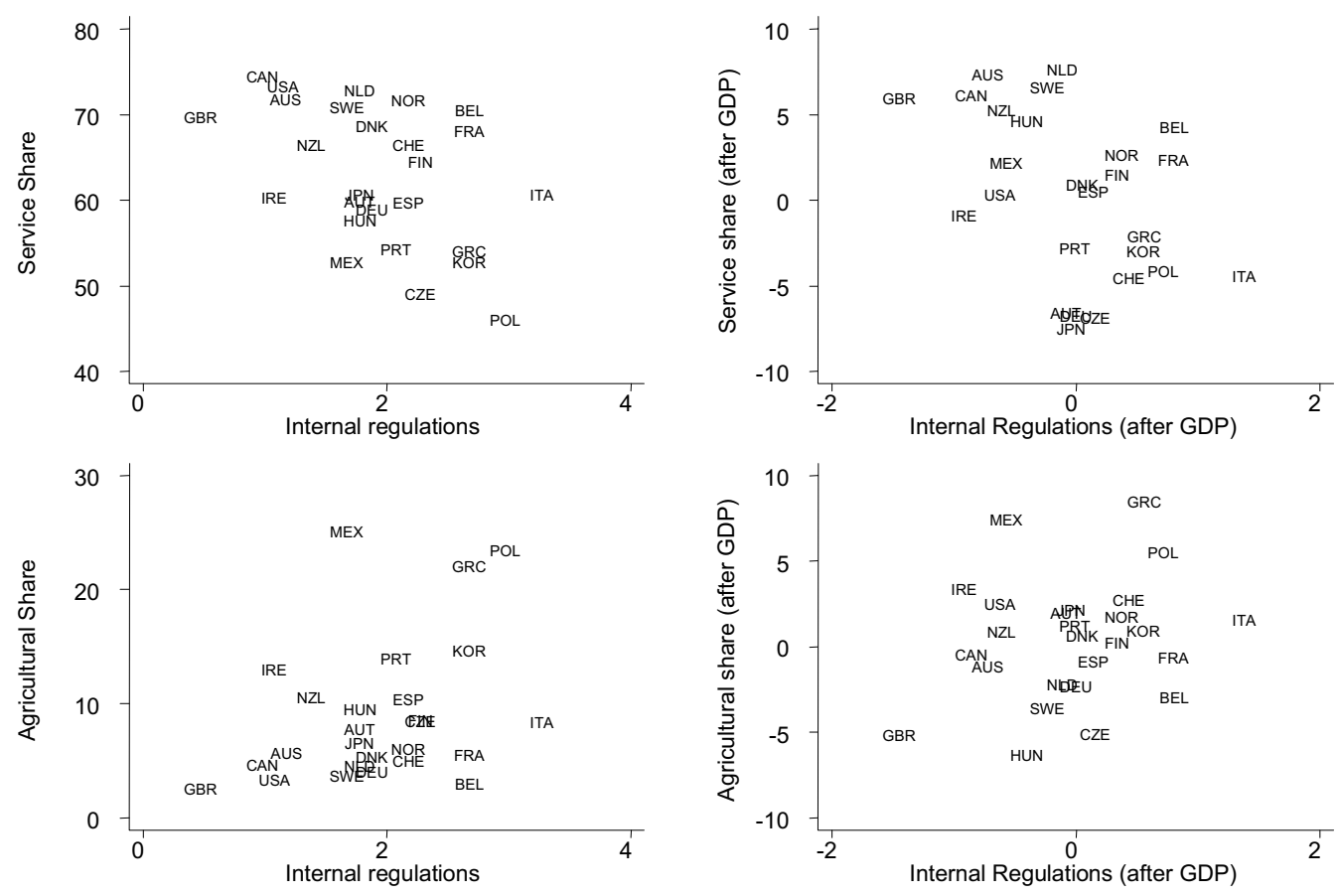

Figure 2: Sectoral Structure and Product Market Regulations across OECD Countries in the 1990s.

The second explanation, first put forward in Baumol (1967), highlights supply side forces. Assuming that labor productivity grows more slowly in services than in industry, and that the ratio of real output between both sectors is held constant, "more and more of the total labor force must be transferred to the non-progressive sector (services) and the amount of labor in the other sector will tend to approach zero". ${ }^{3}$ Accepting the

${ }^{3}$ Baumol (1967) 
caveat that problems of measurement might be attributing real output growth to an increase in the relative price of services, evidence on a slower growth rate in service than in manufacturing "measured" productivity is overwhelming. ${ }^{4}$

Product and labor market institutions should influence the process of structural change, either facilitating or obstructing the reallocation of resources. However, their role has been largely ignored in this literature. ${ }^{5}$ On the labor market side of the regulatory framework, Gordon (1997) suggests that relatively high minimum wages in France could be obstructing the creation of low-wage service industries employment in this country. Along these lines, Freeman and Schettkat (2000) find some evidence of wage compression obstructing the expansion of low skilled services in Germany, although the presence of wage floors is able to account for a minor share of the service employment gap of this country with respect to the US.

Figure 2 presents a first assessment of the relationship between product market regulations and the sectoral employment shares. It shows the association between the average sectoral employment shares in the 1990s and the relative stringency of product market regulations across OECD countries. ${ }^{6}$ A high score in the regulatory indicator stands for less "market friendly" product market regulatory frameworks. Thus, the UK is the most liberal economy in the sample, while Italy appears as the country with more stringent regulations. The graphs on the left hand side show a clear negative (positive) association between the service (agricultural) employment share and the indicator of entry restrictions. Similarly, the partial correlations results (after controlling for GDP per capita) presented on the right hand panels suggest that these correlations are not due to an association between GDP per capita and the indicator of product market regulations. It should be noted that the bivariate correlations between the service employment share and the indicators of product market regulations presented here can be seen at best as suggestive, since other factors might be behind the reported correlations. Messina (2002) shows that the negative association between product market regulations and the service employment share is robust to the incorporation of a large set of controls including indicators of exogenous demand shifts, labor market institutions and trade specialization. Once established this empirical association, the next sections present a model of struc-

\footnotetext{
${ }^{4}$ See for instance Gouyette and Perelman (1997) and the references therein.

${ }^{5}$ An exception is Chenery, Robinson and Syrquin (1986), who mention that institutions that set up barriers to the free movement of factors from low to high productivity growth sectors might be a potential source of slower growth and structural slump.

${ }^{6}$ The indicator of product market regulations is taken from Nicoletti et al. (2001). It encompasses information of several aspects of the regulation of internal product markets, ranging from administrative barriers to business startups to the degree of government intervention and participation in the sector. The correlations presented here are similar to those obtained with other indicators of product market regulations as discussed in Messina (2002).
} 
tural change that spells out the channels through which product market regulations alter the sectoral allocation of resources.

\section{The Model}

In this economy, structural change is brought about by different income elasticities of demand for every good and different exogenous rates of productivity growth across sectors as in Echevarria (1997) and Kongsamut, Rebelo and Xie (2001). There are three sectors: agriculture $(a)$ manufacturing $(m)$ and services $(s)$, each characterized by a continuum of firms $\left(n_{a}, n_{m}, n_{s}\right)$ producing differentiated brands. Product markets are monopolistically competitive,$^{7}$ and entry is restricted due to the existence of regulatory barriers. Thus, the profit function of the a representative firm $i$ in sector $r$ can be defined as follows:

$$
\pi_{i r t}=P_{i t}^{r} C_{i t}^{r}-W_{t} L_{i t}^{r}-P_{t}^{r} \kappa, \text { for } r=a, m, s
$$

where $P_{i t}^{r} C_{i t}^{r}$ and $W_{t} L_{i t}^{r}$ are gross output and the wage bill respectively, and $P_{t}^{r} \kappa$ accounts for product market regulations. In this setting, product market regulations raise economy-wide barriers to entry as a fixed cost (in real terms) of setting up a business that must be paid in every period. This specification is a reasonable approximation to administrative burdens for corporations, price controls or regulatory and administrative opacities in general which represent yearly costs to incumbent firms. Instead, product market regulations such as licenses and permits represent a sunk cost. In this case, $P_{t}^{r} \kappa$ should be interpreted as the annuity payment of those costs. Blanchard and Giavazzi (2002) model this aspect of the regulations in product markets in a similar fashion, considering entry barriers to be proportional to the size of the firm (or firm's output).

In the economy there are three sectors $(r)$ : agriculture $(a)$ manufacturing $(m)$ and services $(s)$, each characterized by a continuum of firms $\left(n^{r}\right)$ producing differentiated brands. Similarly, there is a finite number of households $(M)$, each supplying a differentiated unit of labor $\left(L_{j}\right)$. Let us first turn to the labor demand decisions.

\subsection{Labor Demand}

Technology is the same across sectors and firms, but the exogenous rate of productivity growth $g^{r}$ is allowed to vary across sectors according to the following law of motion

$$
\dot{\lambda}_{t}^{r}=g^{r} \lambda_{t}^{r} \quad, \text { for } \quad r=a, m, s
$$

\footnotetext{
${ }^{7}$ Brunello (1993) incorporates monopolistic competition in product markets and wage bargaining institutions in the unbalanced growth model proposed by Baumol. I differ from him in two fundamental aspects: by allowing for non-homotheticity of preferences and assuming that free entry determines the equilibrium number of firms in every period.
} 
where $\lambda_{t}^{r}$ is the productivity level at time $t$ in sector $r$ and a dot over a variable denotes a derivative with respect to time.

The production function of a representative firm $i$ that operates in sector $r$ can be characterized as

$$
O_{i t}^{r}=M^{\frac{1}{1-\theta}}\left[\sum_{j=1}^{M}\left(L_{i j t}^{r}\right)^{\frac{\theta-1}{\theta}}\right]^{\frac{\theta}{\theta-1}} \lambda_{t}^{r}-\psi^{r} \quad, \text { for } r=a, m, s
$$

The parameter $\psi^{r}$ represents a fixed cost of production that is allowed to vary across sectors but not across firms, while $\theta$ is the elasticity of substitution across the different types of labor and $O_{i t}^{r}$ is the output of firm $i$ in a given period. The first term on the righthand side is a correction factor that controls for the "need for diversity in production". As in Blanchard and Kiyotaki (1987), this implies that the size of the labor force does not increase aggregate production per se.

The problem of the firm can be divided into two subproblems: a labor demand decision and a price decision. Let us consider first the determination of its labor demand. The firm takes the wages of every worker as given, and decides the optimum amount of labor according to technology to minimize its cost function. The solution of this optimization determines labor demand of every particular type of labor $j$, which is inversely related to its wage depending on the elasticity of substitution across labor units $(\theta)$

$$
L_{i j t}^{r}=\frac{1}{M \lambda_{t}^{r}}\left(\frac{W_{t}}{W_{j t}}\right)^{\theta}\left(O_{i t}^{r}+\psi^{r}\right)
$$

in which $W_{t}$ is the aggregate wage

$$
W_{t}=\left(\frac{1}{M} \sum_{j=1}^{M}\left(W_{j t}\right)^{1-\theta}\right)^{\frac{1}{1-\theta}}
$$

Aggregation across brands and sectors yields total labor demand for labor type $j$ :

$$
\begin{aligned}
L_{j t} & =\sum_{i=1}^{n_{t}^{a}} L_{i j t}^{a}+\sum_{i=1}^{n_{t}^{m}} L_{i j t}^{m}+\sum_{i=1}^{n_{t}^{s}} L_{i j t}^{s}= \\
& =\frac{1}{M}\left(\frac{W_{t}}{W_{j t}}\right)^{\theta} \sum_{r=a, m, s}\left[\left(\sum_{i=1}^{n_{t}^{r}} O_{i t}^{r}+n_{t}^{r} \psi^{r}\right)\left(\lambda_{t}^{r}\right)^{-1}\right]
\end{aligned}
$$

\subsection{Households}

There is a finite number of identical households $M$, with non-homothetic preferences among the three consumption goods as in Kongsamut, Rebelo and Xie (2001). Each 
household is the monopolist supplier of a particular type of labor, ${ }^{8}$ deciding optimally among consumption and leisure according to the maximization of the utility function

$$
U_{j t}=\left(\left(C_{j t}^{a}-\bar{A}\right)^{\alpha}\left(C_{j t}^{m}\right)^{\beta}\left(C_{j t}^{s}+\bar{S}\right)^{1-\alpha-\beta}\right)^{\phi}\left(\bar{L}-L_{j t}\right)^{1-\phi}
$$

where $C_{t}^{a}, C_{t}^{m}$ and $C_{t}^{s}$ are composite bundles that represent the total amount of agricultural, manufacturing and service goods consumed at time $t$. The parameter $\bar{A}$ is a subsistence level of agricultural goods, implying that the poorer the household is, the more of its income must be devoted to the consumption of food. In other words, given $\bar{A}>0$ the income elasticity of agricultural demand is lower than 1 . On the other hand, $\bar{S}$ can be interpreted as home production of service activities like cooking, cleaning or home repairs, to name but a few, accounting for the assumption that as GDP grows, there is a progressive monetization of these activities. ${ }^{9}$ Thus, given $\bar{S}>0$ the income elasticity of demand for services is always greater than 1 . The second term of the utility function represents leisure, $\bar{L}$ being the household endowment of hours. The budget constraint and non-negativity conditions for the household utility maximization are the following:

$$
\begin{aligned}
P_{t}^{a} C_{j t}^{a}+P_{t}^{m} C_{j t}^{m}+P_{t}^{s} C_{j t}^{s} & \leq W_{j t} L_{j t}+R_{j t} \\
C_{j t}^{a} & \geq 0, \quad C_{j t}^{m} \geq 0, \quad C_{j t}^{s} \geq 0
\end{aligned}
$$

where $P_{t}^{a}, P_{t}^{m}$ and $P_{t}^{s}$ are the agriculture, manufacturing and service price indices that will be defined below. The right-hand side of the inequality in (8) represents total disposable income of the household, that is composed of labor income $\left(W_{j t} L_{j t}\right)$ and a share $\left(R_{j t}\right)$ in the rents of the economy. Every household is the owner of an equal share of the firms. Thus, from eq. (1) it follows that

$$
R_{j t}=\frac{\kappa}{M} \sum_{r=a, m, s} P_{t}^{r} n_{t}^{r}
$$

In each sector, $n_{t}^{r}$ varieties are produced every period, and each household chooses among these varieties according to the following sub-utility function:

$$
C_{j t}^{r}=\left(n_{t}^{r}\right)^{\xi^{r}}\left(\sum_{i=1}^{n_{t}^{r}}\left(C_{i j t}^{r}\right)^{\frac{\sigma^{r}-1}{\sigma^{r}}}\right)^{\frac{\sigma^{r}}{\sigma^{r}-1}} \quad ; \quad \text { for } r=a, m, s
$$

\footnotetext{
${ }^{8}$ As Blanchard and Kiyotaki (1987) point out, each household can be seen as a craft union, monopolizing a particular type of labor.

${ }^{9}$ Another secular trend is the progressive substitution of some of these services by goods that carry out the same functions, like washing machines and dish-washers. The decision between purchasing these services in the market or substituting them by manufacturing goods will depend, among other factors, on the evolution of relative prices. Therefore, the stringency of product market regulations will have an important role in this process as will be discussed later.
} 
where $\sigma^{r}>1$ is the elasticity of substitution among varieties in sector $r$. I follow the original setup proposed by Dixit and Stiglitz (1975) in the working paper version of their paper, by assuming that the number of varieties of each composite good $\left(n_{t}^{r}\right)$ enters explicitly the utility function up to an arbitrary power $\left(\xi^{r}\right)$. This assumption will be important for the analysis later, inasmuch as it allows variety to be a public good $\left(\xi^{r}>0\right)$ or a public bad $\left(\xi^{r}<0\right)$. It therefore encompasses several specifications that have been used in the literature. For instance, by setting $\xi^{r}=\frac{1}{1-\sigma^{r}}$ test for variety is cancelled as in Blanchard and Kiyotaki (1987), while $\xi^{r}=0$ is the functional form preferred by Dixit and Stiglitz (1977) in the published version of their paper.

Note that within this framework, the price index for composite good $r$ can be written as

$$
P_{t}^{r}=\left(n_{t}^{r}\right)^{-\xi^{r}}\left(\sum_{i=1}^{n_{t}^{r}}\left(P_{i t}^{r}\right)^{1-\sigma^{r}}\right)^{\frac{1}{1-\sigma^{r}}}, \text { for } r=a, m, s
$$

which is independent of the prices and quantities consumed of goods which do not belong to group $r$. Thus, weakly homogeneous separability applies and two-stage budgeting is a valid procedure. ${ }^{10}$ This implies that every household decides first how much to consume out of agricultural, manufacturing and service goods taking aggregate expenditure as given, and next decides how to allocate sectoral expenditures to individual commodities.

In the first stage, sectoral expenditures and labor supply are decided. Therefore, the household maximizes its utility function (7) subject to the budget constraint (8) and labor demand for its particular type of labor (6). This yields the following demand functions

$$
\begin{gathered}
C_{j t}^{a}=\frac{\alpha}{P_{t}^{a}} I_{j t}+\bar{A} \\
C_{j t}^{m}=\frac{\beta}{P_{t}^{m}} I_{j t} \\
C_{j t}^{s}=\frac{1-\alpha-\beta}{P_{t}^{s}} I_{j t}-\bar{S}
\end{gathered}
$$

where $I_{j t}$ is the so-called full income of the household:

$$
I_{j t}=W_{j t} L_{j t}+R_{j t}+P_{t}^{s} \bar{S}-P_{t}^{s} \bar{A}
$$

and the individual labor supply schedule

$$
L_{j t}=\bar{L}-\frac{(1-\phi)}{\phi} \frac{\theta}{(\theta-1)} \frac{I_{j t}}{W_{j t}}
$$

\footnotetext{
${ }^{10}$ For an exposition of the concept and conditions for weak homogeneous separability see Diewert and Wales (1995) and the references therein.
} 
with $\frac{\theta}{(\theta-1)}$ representing a markup over the marginal utility of leisure and $\frac{(1-\phi)}{\phi}$ the ratio between the elasticities of the marginal utilities of leisure and consumption.

In the second stage households allocate sectoral expenditures to individual commodities. Thus, every household repeats for every sector the maximization of (9) subject to

$$
\sum_{i=1}^{n_{t}^{r}} P_{i t}^{r} C_{j i t}^{r}=P_{t}^{r} C_{j t}^{r}, \quad \text { for } r=a, m, s
$$

This yields the demands for every variety, which are inversely related to its relative price according to the inter-brand elasticity of substitution,

$$
C_{j i t}^{r}=\left(\frac{P_{t}^{r}}{P_{i t}^{r}}\right)^{\sigma^{r}} C_{j t}^{r}\left(n_{t}^{r}\right)^{\xi^{r}\left(\sigma^{r}-1\right)}, \quad \text { for } r=a, m, s
$$

Aggregating across households, total demand of good $i$ becomes

$$
C_{i t}^{r}=\sum_{j=1}^{M} C_{j i t}^{r}=\left(\frac{P_{t}^{r}}{P_{i t}^{r}}\right)^{\sigma^{r}}\left(n_{t}^{r}\right)^{\xi^{r}\left(\sigma^{r}-1\right)} \sum_{j=1}^{M} C_{j t}^{r}, \quad \text { for } \quad r=a, m, s
$$

\subsection{Price Rule}

Taking into account the demand for each particular brand and the available technology, the monopolistic firms set prices to maximize profits. By assumption, the number of firms (and therefore brands) is so large that every firm neglects the indirect effects of its price decisions on aggregate variables. The goods produced are non-storable.

From labor demand of every type of labor (4) and the definition of aggregate wages (5), firms' $i$ cost function becomes

$$
\sum_{j=1}^{M} W_{j t} L_{i j t}^{r}=W_{t}\left(O_{i t}^{r}+\psi_{t}^{r}\right)\left(\lambda_{t}^{r}\right)^{-1}
$$

Profit maximization of firms' $i$ profits (1) subject to its demand (16) and cost function (17) yields the price rule

$$
P_{i t}^{r}=\mu^{r} \frac{W_{t}}{\lambda_{t}^{r}} \quad, \text { for } \quad r=a, m, s
$$

where

$$
\mu^{r}=\frac{\sigma^{r}}{\sigma^{r}-1} \quad, \quad \text { for } \quad r=a, m, s
$$

is the markup of prices over marginal costs. 


\subsection{Equilibrium}

First note that in the light of the assumptions made about technology and preferences, the inter-brand equilibrium will be symmetrical:

$$
\begin{array}{cl}
P_{j t}^{r} & =P_{k t}^{r} \quad \forall j, k \quad \text { for } r=a, m, s \\
W_{j t} & =W_{k t}=W_{t} \quad \forall j, k
\end{array}
$$

Symmetry allows us to work with aggregate variables. Taking into account the symmetry in brand prices, from eq. (10) the aggregate sectoral price index becomes

$$
P_{t}^{r}=\left(n_{t}^{r}\right)\left(\frac{\xi^{r} \sigma^{r}+1-\xi^{r}}{1-\sigma^{r}}\right) P_{j t}^{r} \quad, \text { for } r=a, m, s
$$

which implies that, as long as taste for variety is not cancelled $\left(\xi^{r}>\frac{1}{1-\sigma^{r}}\right)$, sectoral prices decrease when the number of varieties in each sector increases. ${ }^{11}$ Introducing (20) into (18) an expression for aggregate sectoral prices is obtained:

$$
P_{t}^{r}=\left(n_{t}^{r}\right)^{\left(\frac{\xi^{r} \sigma^{r}+1-\xi^{r}}{1-\sigma^{r}}\right)} \mu^{r} \frac{W_{t}}{\lambda_{t}^{r}} \quad, \text { for } r=a, m, s
$$

Combining (16) and (20), demand for every brand becomes

$$
C_{i t}^{r}=\left(n_{t}^{r}\right)^{\left(\frac{\xi^{r} \sigma^{r}+\sigma^{r}-\xi^{r}}{1-\sigma^{r}}\right)} \sum_{j=1}^{M} C_{j t}^{r}=\left(n_{t}^{r}\right)^{\left(\frac{\xi^{r} \sigma^{r}+\sigma^{r}-\xi^{r}}{1-\sigma^{r}}\right)} C_{t}^{r} \quad, \quad \text { for } \quad r=a, m, s
$$

Similarly, from symmetry and market clearing in (4), labor demand in every sector can be expressed as

$$
\left(L_{t}^{r}\right)^{D}=\frac{1}{\lambda_{t}^{r}}\left(\left(n_{t}^{r}\right)^{\left(\frac{\xi^{r}-\xi^{r} \sigma^{r}-1}{\sigma^{r}-1}\right)} C_{t}^{r}+n_{t}^{r} \psi^{r}\right) \quad, \text { for } \quad r=a, m, s
$$

while individual labor supply (15) becomes

$$
\left(L_{j t}\right)^{S}=\phi \frac{1-\theta}{\phi-\theta} \bar{L}-\frac{(1-\phi)}{\theta-\phi} \frac{\theta}{W_{t}}\left(R_{j t}+P_{t}^{s} \bar{S}-P_{t}^{a} \bar{A}\right)
$$

From (24) and (24) labor markets clear according to

$$
L_{t}^{a}+L_{t}^{m}+L_{t}^{s}=M\left(\phi \frac{1-\theta}{\phi-\theta} \bar{L}-\frac{(1-\phi)}{\theta-\phi} \frac{\theta}{W_{t}}\left(R_{j t}+P_{t}^{s} \bar{S}-P_{t}^{a} \bar{A}\right)\right)
$$

Aggregating over households, once symmetry is applied to the demand equations, (11), (12) and (13) become

$$
C_{t}^{a}=\frac{\alpha M}{P_{t}^{a}}\left(W_{t} L_{j t}+R_{j t}+P_{t}^{s} \bar{S}-P_{t}^{s} \bar{A}\right)+M \bar{A}
$$

\footnotetext{
${ }^{11}$ Note that aggregate wages are equal to individual wages, which implies that there are not scale effects from the number of types of workers in the economy. The reason for this asymmetry with respect to aggregate prices is that we controlled for "need for diversity" in production.
} 


$$
\begin{gathered}
C_{t}^{m}=\frac{\beta M}{P_{t}^{m}}\left(W_{t} L_{j t}+R_{j t}+P_{t}^{s} \bar{S}-P_{t}^{s} \bar{A}\right) \\
C_{t}^{s}=\frac{(1-\alpha-\beta) M}{P_{t}^{s}}\left(W_{t} L_{j t}+R_{j t}+P_{t}^{s} \bar{S}-P_{t}^{s} \bar{A}\right)-M \bar{S}
\end{gathered}
$$

An expression for the equilibrium number of firms in every sector closes the model. Let us assume free entry once the regulatory costs are satisfied. Then, combining (1), (21) and (22), the zero profit condition and market clearing set the number of varieties in every sector according to the next expression

$$
C_{t}^{r}\left(\mu^{r}-1\right)-\left(n_{t}^{r}\right)^{\left(\frac{\xi^{r} \sigma^{r}+\sigma^{r}-\xi^{r}}{\sigma^{r}-1}\right)} \psi^{r}-\mu^{r} n_{t}^{r} \kappa=0 \quad \text { for } \quad r=a, m, s
$$

Equilibrium is defined by the three demand rules (26), (27), (28), the three price equations summarized in (21), the three labor demand equations (23), the three zero profit conditions (29) and the labor market clearing condition (25), which constitute a system of 13 equations in 13 unknowns. Labor is set as the numeraire such that wages are equal to 1 . Nevertheless, non linearities in the system obliged to find numerical solutions by an iterative process.

\subsection{Parameterization}

All parameters are set in advance to match certain long-run averages observed in the US economy of the last century. Thus, a model period corresponds to one year and the model is simulated for 100 periods.

Table 1 summarizes the parameters used in the benchmark simulations. The expenditure shares $(\alpha, \beta)$ represent the actual sectoral value added as a percentage of GDP in the US in 2000. $\bar{A}$ and $\bar{S}$ are set together with the initial levels of technology $\left(g_{0}^{a}, g_{0}^{m}, g_{0}^{s}\right)$ in order to obtain an income elasticity of demand for every good consistent with empirical estimates. Accordingly, the average income elasticity of service demand in a mature economy (during the last 20 periods of the simulation) is 1.1, consistent with available estimates for the 1980s (Bergstrand, 1991). Over the whole period, the income elasticity of demand for services is larger than one, and decreases monotonically as productivity increases. Consistent with the empirical evidence, the income elasticity for manufactures is smaller than for services but larger than for agriculture.

Oliveira, Scarpetta and Pilat (1996) find an average mark-up of 1.15 for US manufacturing, while estimates for service sub-sectors range from 1.24 to 1.68. I introduce the same markups in the three sectors in the benchmark simulation to isolate the effects of entry barriers on the sectoral structure. Therefore, the elasticity of substitution across brands in every sector is set to 6 , which implies a markup of 1.2.

The value of $\phi$ is set to $1 / 3$ such that in the absence of product market regulations and income effects due to non-homothetic preferences every household would work a third 
Table 1:

Parameters in the Baseline Model

\begin{tabular}{|c|c|c|c|c|c|c|c|c|c|c|c|}
\hline$g_{0}^{a}$ & $g_{0}^{m}$ & $g_{0}^{s}$ & $\alpha$ & $\beta$ & $\bar{A}$ & $\bar{S}$ & $\phi$ & $L$ & $\xi^{a}$ & $\xi^{m}$ & $\xi^{s}$ \\
\hline 1000 & 200 & 300 & 0.02 & 0.025 & 600 & 100 & $1 / 3$ & 2 & 0 & 0 & 0 \\
\hline \hline$M$ & $g^{a}$ & $g^{m}$ & $g^{s}$ & $\mu^{a}$ & $\mu^{m}$ & $\mu^{s}$ & $\psi^{a}$ & $\psi^{m}$ & $\psi^{s}$ & $\theta$ & $\kappa$ \\
\hline 50 & 0.033 & 0.022 & 0.011 & 1.2 & 1.2 & 1.2 & 50 & 50 & 50 & 6 & 300 \\
\hline
\end{tabular}

of its time endowment. The household time endowment is set to 2 , and the number of households to 50 , so that the employment rate could be easily expressed as a percentage. Fixed costs of production are set to 50 in the three sectors. ${ }^{12}$

The growth rates of sectoral productivity $\left(g^{a}, g^{m}, g^{s}\right)$ are calculated using data described in Broadberry (1998). This data represent yearly average annual growth rates of output per employee in the main sectors of the US economy for the period 1900-1990. ${ }^{13}$ According to these estimates, service productivity growth lags behind the other two sectors as put forward by Baumol's cost-disease model.

In the benchmark simulations, the degree of taste for variety $\left(\xi^{r}\right)$ is set to zero in all sectors. Therefore, as in Dixit and Stiglitz (1977) variety is neither a public good nor a bad. Finally, $\kappa$ is set to 300 , implying that when product markets are regulated rents account for $12 \%$ of annual GDP in a mature economy.

\section{Long-Run. The Free Entry Case}

Let us first concentrate on the dynamics of the model in the long run free entry case; thus, when barriers to entry are absent $(\kappa=0$ in eq. (1)). Figure 3 shows the simulated evolution of the real and nominal sectoral GDP shares, sectoral employment shares and employment rate for a period of 100 years. First, note that the sectoral employment shares follow a remarkably similar pattern to the one observed in the US economy during the last century (reported in Figure 1). A massive reallocation of employment from agricultural to service industries takes place, while the manufacturing employment share remains relatively constant. In early stages of production (when productivity is

\footnotetext{
${ }^{12}$ This choice will become relevant when we assess the effects of different levels of product market regulations. The consequences of the relative size of the fixed costs with respect to the costs of regulations will be discussed in Section 5.1.

${ }^{13}$ The service sector productivity growth rate is a weighted average of Distribution, Transport and Communications, Utilities, Finance and Other Services rates of productivity growth. Government Services are left out of the analysis, since output measurement rules out the possibility of productivity growth in this sector.
} 
low), the subsistence level of agricultural consumption requires a large share of employment engaged in this sector. However, the important growth rate of productivity in the agricultural sector frees up so much employment that initially both manufacturing and service employment shares increase. This pattern remains stable during the first 50 years of the simulation. Afterwards, the income elastic demand for services together with the low rate of productivity growth in this sector brings about a continuously increasing share of services in employment and nominal GDP, which starts drawing resources even from the manufacturing sector.

Even if the service share increases in nominal terms, following the same pattern of the employment shares, the effects of the productivity gap can be observed from the evolution of the real GDP shares. ${ }^{14}$ As income rises, the gap between productivity in manufacturing and services grows, and consequently the relative price of services increase with respect to manufacturing. Thus, given the constant raise of the relative price of services, the evolution of the real GDP shares illustrates the so-called cost-disease evolution of the service sector, which suggests that a non-negligible part of the expansion of services nominal GDP shares is due to this price differential.

The evolution of the employment rate can be easily understood from the market clearing condition in the labor market (25) which, taking into account that in the free entry case rents are zero $\left(R_{t}=0\right)$ becomes :

$$
L_{t}^{a}+L_{t}^{m}+L_{t}^{s}=M\left(\phi \frac{1-\theta}{\phi-\theta} \bar{L}-\frac{\theta(1-\phi)}{\theta-\phi} \frac{\left(P_{t}^{s} \bar{S}-P_{t}^{a} \bar{A}\right)}{W_{t}}\right)
$$

Therefore, if preferences were homothetic $(\bar{A}=\bar{S}=0)$, the employment rate would be fixed over time at $\phi \frac{1-\theta}{\phi-\theta} \bar{L}$ (dashed-horizontal line in the graph). Instead, within our framework households take into account the endowment of services and subsistence requirement of food when deciding labor supply. Note that as productivity increases (and prices fall) the relative importance of these endowments declines, which implies that structural change progressively faints and the employment rate tends to $\phi \frac{1-\theta}{\phi-\theta} \bar{L}$ in the long run.

Along the structural change path the same forces that explain the sectoral employment shares drive the evolution of labor supply. At early stages of development (small $t$ ) the need to fulfill the subsistence level of agriculture consumption together with a low labor productivity in the three sectors explains that the hours worked are above $\phi \frac{1-\theta}{\phi-\theta} \bar{L}$. As income grows, households progressively reduce their working hours, since productivity

\footnotetext{
${ }^{14}$ Real GDP shares are defined as sectoral output evaluated at prices in period 80 divided by real GDP as obtained using a Paasche price index. Thus, the expresion for the real GDP share in sector $r$ becomes: $\left(\frac{P_{r 80} C_{r t}}{\sum_{r} P_{r t} C_{r t}}\right)\left(\frac{\sum_{r} P_{r t} C_{r 80}}{\sum_{r} P_{r 80} C_{r 80}}\right)$
} 

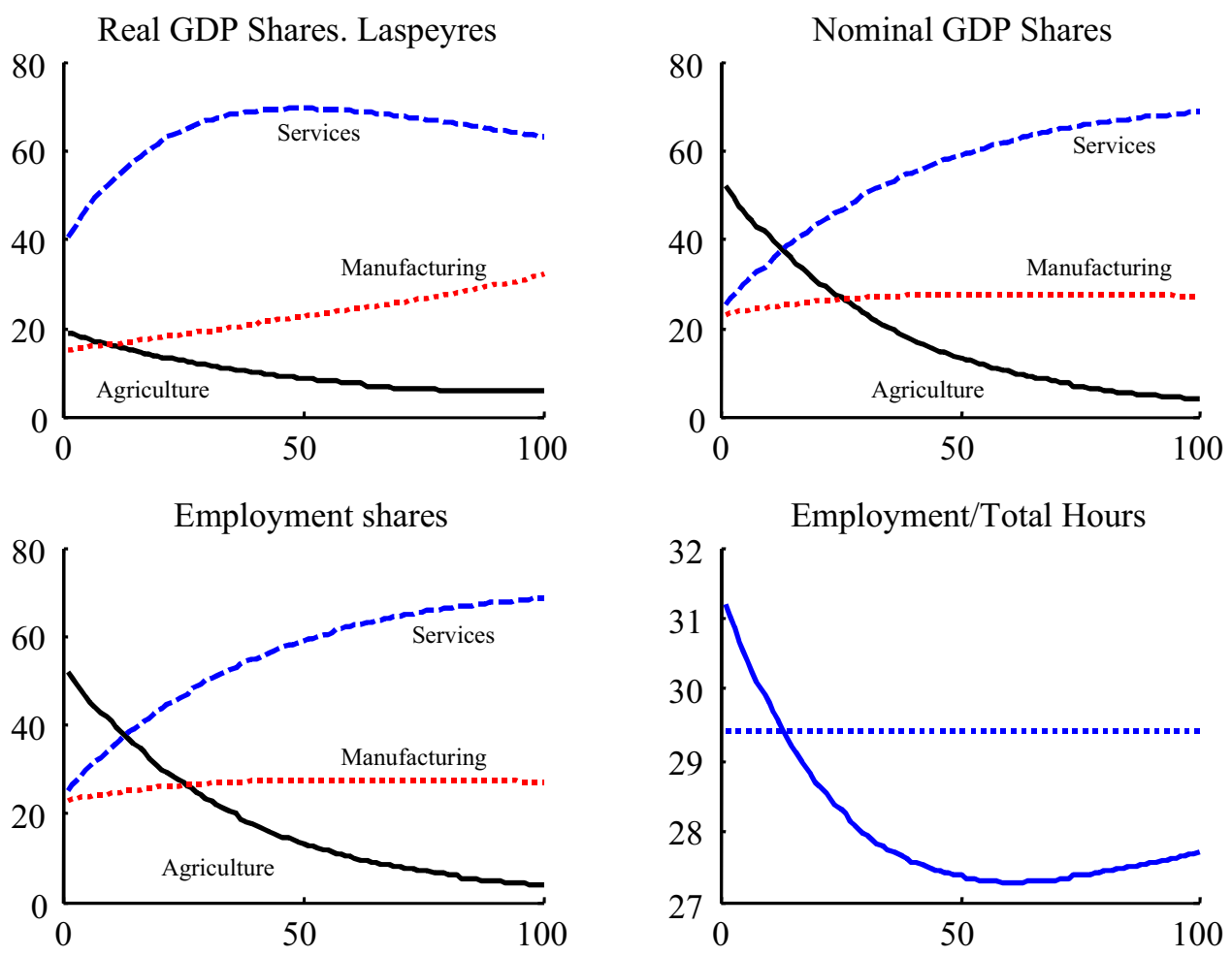

Figure 3: Long Run Evolution. Free Entry Case

growth means that the subsistence level of food consumption can be reached with fewer hours of work. This decline in per capita hours worked coincides with the shift away from employment engaged in agricultural production, as observed in the early decades of the twentieth century in the US (Costa, 1994). At some point, the value of home production of services equals the agricultural subsistence requirement, and the employment rate crosses the long-run equilibrium level of leisure. Finally, the continuous reduction of service prices implies a fall in the relative value of home production with respect to market purchase of services that explains the rise in labor supply.

\section{Introducing Product Market Regulations}

Last section showed that the model can capture the stylized facts of structural change. However, non-homotheticity of preferences and different sectoral productivity growth rates are not enough to explain cross-country variability of sectoral labor shares as long as 

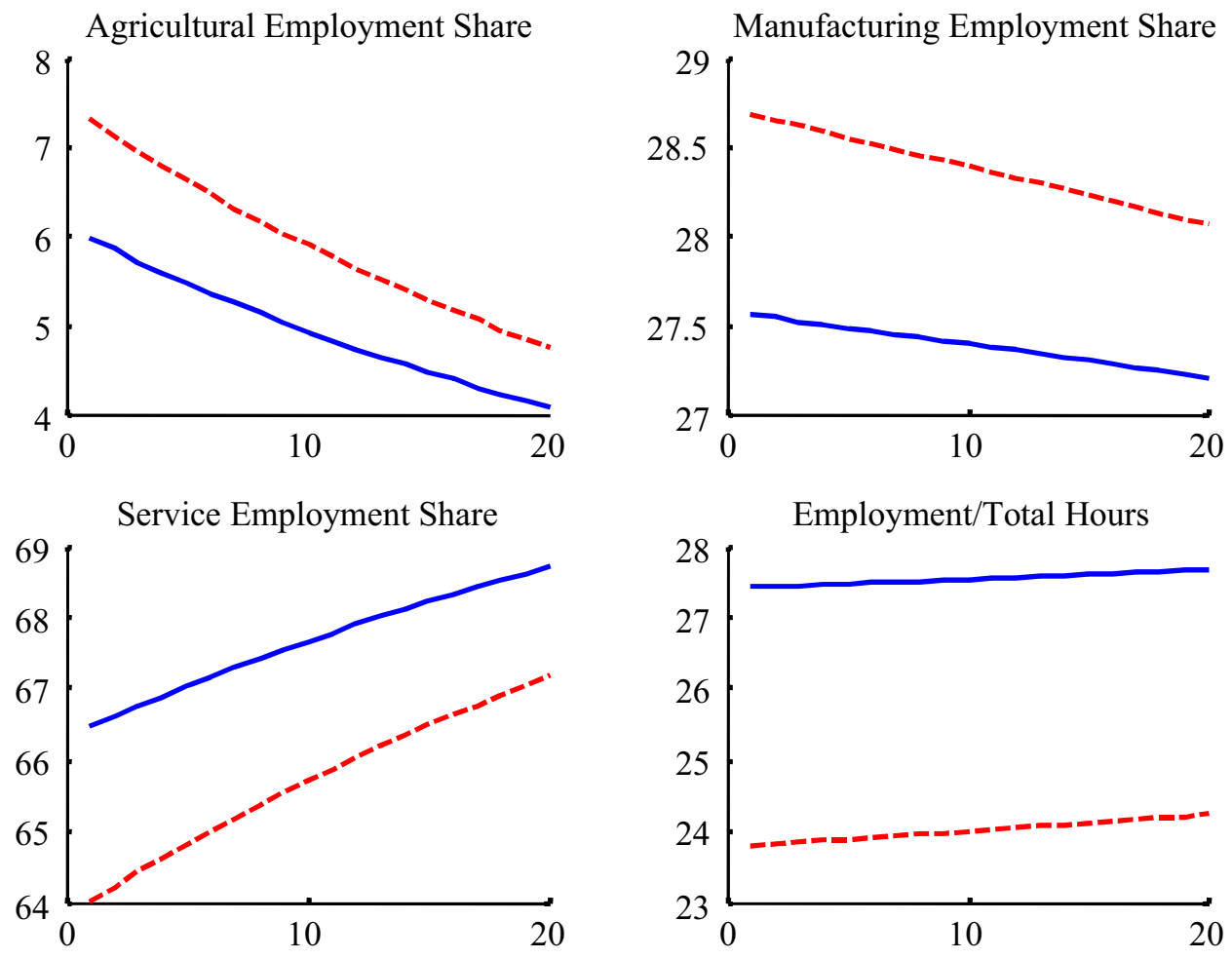

Figure 4: Employment Shares and Working Hours in a Mature Economy

preferences and technology are similar across a pool of relatively homogenous countries.

The next simulation studies the effects of regulations in product markets on the sectoral allocation of employment and labor supply decisions. Since the empirical motivation of this paper is the divergence in the sectoral employment shares across mature economies, the time span in the simulation is limited to the last 20 years.

Figure 4 shows the employment rate and sectoral labor shares for the unrestricted entry model (straight lines) and the regulated model (dashed lines). The comparison of the employment rates in the regulated and free entry economies clearly shows that more stringent regulatory barriers reduce labor supply. The intuition behind this result is quite simple. Total differentiation of (24) yields:

$$
\frac{d\left(L_{j t}\right)^{S}}{d \kappa}=-\chi\left(\frac{d R_{j t}}{d \kappa}+\bar{S} \frac{d P_{t}^{s}}{d \kappa}-\bar{A} \frac{d P_{t}^{a}}{d \kappa}\right)
$$

where $\chi$ is a positive constant. The first term in the parenthesis is positive, indicating that barriers to entry reduce labor supply directly through the raise in the size of the 
rents in the economy. The other two terms show that entry barriers alter labor supply through changes in the value of the subsistence requirements. Since tighter product market regulations reduce the number of firms in equilibrium, the prices of agricultural and service products increase according to eq. (21). The raise in the value of home production of services $\left(P_{t}^{s} \bar{S}\right)$ in the presence of barriers to entry acts as an income effect that further reduces labor supply. This is partially offset by the increasing cost of the subsistent requirement of food (third term). However, this is a second order effect in relatively wealthy societies, where the consumption expenditure in agricultural products is very modest and the fast productivity experienced in this sector guarantees a low relative price for food. Thus, the first two effects outweigh the latter and labor supply falls in regulated economies. ${ }^{15}$

Nicoletti et al. (2001) find a negative correlation between product market regulations and the employment rate in a cross-country study for OECD economies. While they discuss several demand-side channels that could drive this finding, the model presented here proposes an alternative explanation. As product market regulations become more stringent, the reduction of varieties increases rents and service prices and favor home production of service activities against their purchase in the market, reducing labor supply. Similarly, Freeman and Schettkat (2002) find that once home production of services is accounted for, there are no sizable differences in the employment rate between the US and Germany. As the authors put forward, differences in the tax wedge and skills distributions between both countries partly explain the gap. Additionally, according to the insights discussed above the lower labor supply of German households might be the response to more stringent product market regulations (and therefore higher service prices).

The first three panels of Figure 4 show the responses of the sectoral employment shares to the presence of regulatory barriers. They show that economy-wide barriers to entry exert asymmetric effects on the productive structure of an economy characterized by structural change. They reduce the labor engaged in service activities, increasing the sectoral employment shares of manufacturing and agriculture.

The rationale behind this result is the following. First, entry barriers reduce the number of firms and therefore varieties in every sector. Variety is a valuable asset for households, and therefore its reduction increases prices of all goods reducing utility-based real income. Since service demand is income elastic, as long as the introduction of entry restrictions reduces real income this causes a reduction in consumption that is stronger for the service sector. ${ }^{16}$ Second, the higher market price of services and larger size of

\footnotetext{
${ }^{15}$ Alternative simulations where barriers to entry represent a dead-weight loss show that these institutions reduce the employment rate in a mature economy even in the absence of rents.

${ }^{16}$ Note that this reduction in utility-based real income will not always take place. Less varieties in the
} 
Welfare Loss

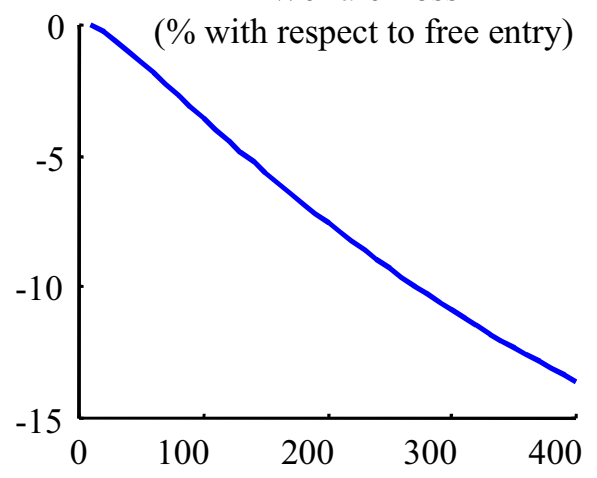

Employment Rate Differential

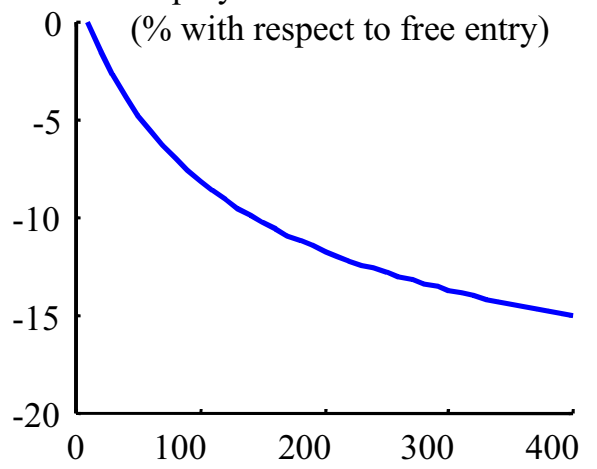

Service Share Differential

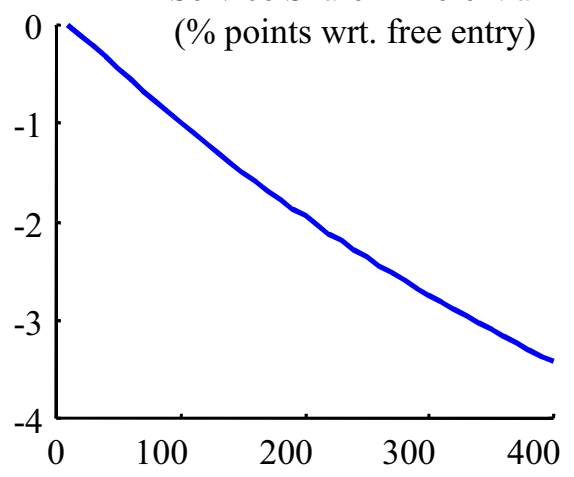

Rents/GDP (\%)

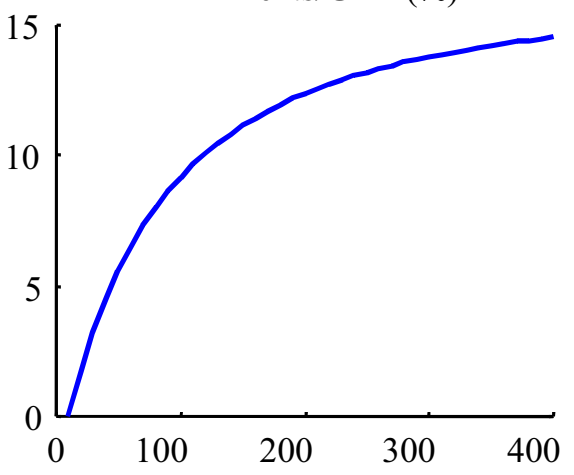

Figure 5: Relative Stringency of Product Market Regulations and Aggregate Outcomes.

rents in the regulated economy triggers an additional income effect via reduction of labor supply which constrains further the service employment share.

Dixit and Stiglitz (1977) show that when $\xi=0$ the number of varieties in market equilibrium is equal to the second best social optimum (where lump-sum subsidies to overcome the inefficiency introduced by monopolistic firms are not available). It can be shown that this result is not affected by non-homotheticity of preferences. Therefore, it is straightforward that the introduction of product market regulations reduces welfare in this context. It is interesting however to see how important these welfare losses are. In order to measure the magnitude of the welfare losses introduced by regulations in product markets, let us define $\vartheta$ as the percentage variation in leisure that an individual in a regulated economy has to experience to be as well off as in the free entry case, leaving consumption constant. If subscripts $p$ denote variables in the regulated equilibrium and

presence of product market regulations increase sectoral prices but also saves fixed costs of production. The first effect outweighs the latter when $\xi \geq 0$. Next section discusses this trade-off in further detail. 
subscripts $f$ are meant for the free entry parameterization, omitting individual subscripts for simplicity, the welfare losses $(-\vartheta)$ are implicitly defined as:

$$
U_{t}\left(C_{f t}^{a}, C_{f t}^{m}, C_{f t}^{s},\left(\bar{L}-L_{f t}\right)\right)=U_{t}\left(C_{p t}^{a}, C_{p t}^{m}, C_{p t}^{s},\left(\bar{L}-L_{p t}\right)\left(1+\frac{\vartheta}{100}\right)\right)
$$

Figure 5 shows a monotonic relation between $\kappa$ and the compensating variation in leisure. It also plots the differentials between the regulated and the free entry benchmark economies in the employment rate and the service share. These results highlight the relative importance of regulatory barriers to entry, predicting welfare losses of almost $10 \%$ with respect of the free entry case and sizable reductions of the service share and the employment rate when the size of rents represent $10 \%$ of GDP. Finally, note that in the model barriers to entry are equally spread across sectors. To the extent that in reality product market regulations are concentrated in service industries, their effects on the employment rate and service employment share will be underestimated in the simulations presented here.

\subsection{Discussion. Taste for variety as a public good}

Previous sections analyzed the Dixit and Stiglitz (1977) case, in which taste for variety is neither a public good nor a bad $(\xi=0)$. The debate about the optimal number of varieties is obviously more complicated in reality than in our stylized model. Not even the definition of variety is generally accepted. A signal of this debate can be extracted from the current discussion in Europe about the regulatory framework in the retail distribution sector. On the one hand, a sector of the population desires a movement towards a less stringent regulation regarding shop opening hours and restrictions on large-scale outlets. Among other arguments, they claim that these regulations limit the expansion of large stores which through economies of scale and scope would be able to offer a larger range of services (e.g. home delivery, longer opening hours) at lower prices. On the other hand, the supporters of more stringent regulations sustain that by protecting small retail outlets such regulations might increase prices but at the same time increase the range of services offered (for instance, proximity services) and therefore the number of varieties available in the economy.

However, the retail sector constitutes a very special case, where there is imperfect substitution between large and small outlets. In many other sectors, the issue of the optimal number of varieties essentially reduces to the trade-off between economies of scale and how variety is socially valued.

In the model, the reduction of varieties that occurs when product market regulations are present increase sectoral prices according to (21). In the case in which variety is a public good $(\xi>0)$ this price effect is larger than in the simulations presented in the 


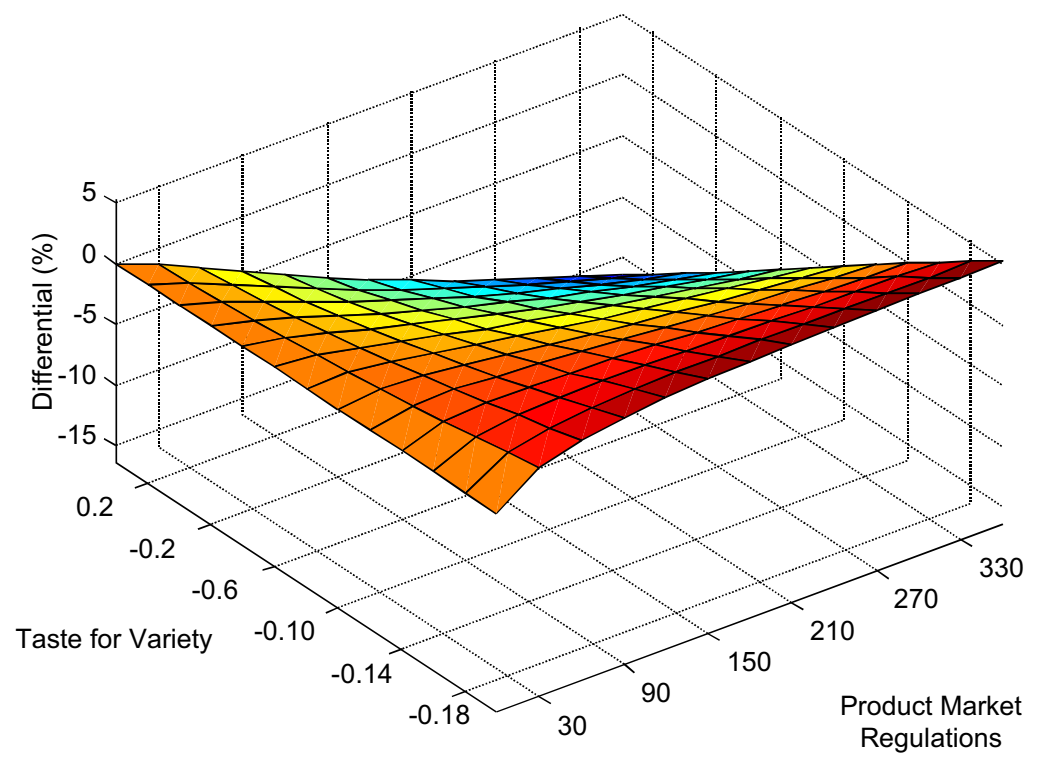

Figure 6: Welfare Difference with Respect to the Free Entry Case

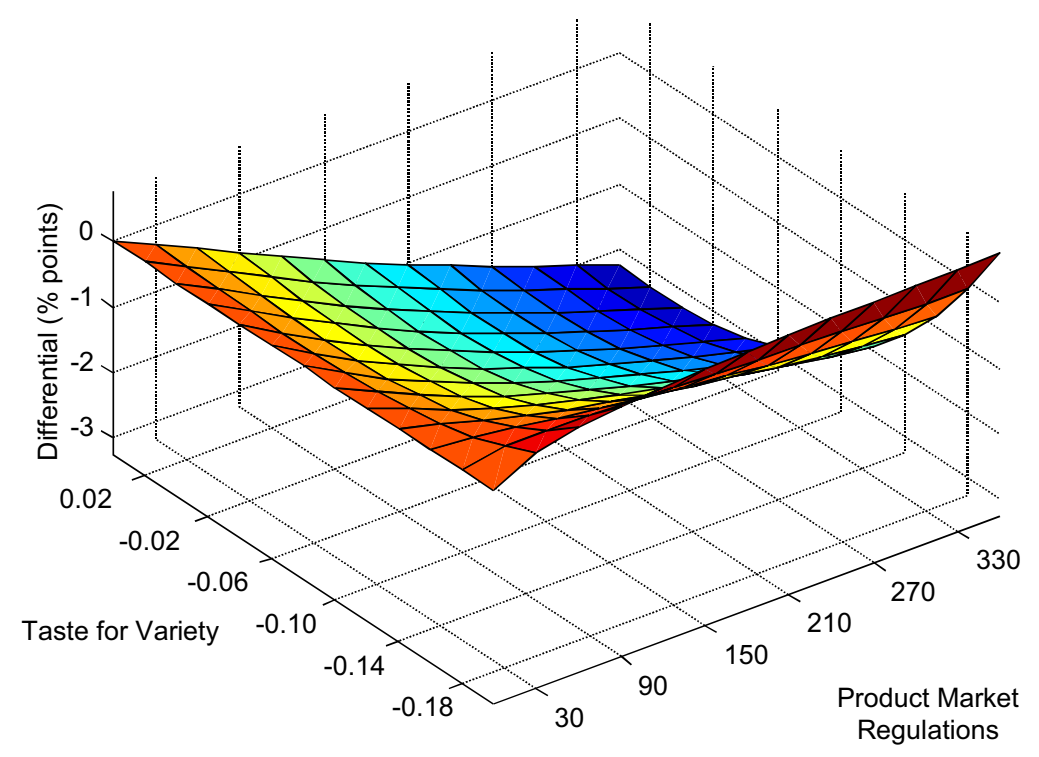

Figure 7: Service Employment Difference (percentage points) with Respect to the Free Entry Case 
previous sections, reinforcing the main conclusions obtained above. However, if variety is a public bad, $(\xi<0)$ no general conclusions can be obtained. In the limit case in which taste for variety is cancelled $\left(\xi=\frac{1}{1-\sigma}\right)$ it can be easily seen from eq. (21) that sectoral prices do not depend on the number of varieties. Therefore, since product market regulations reduce the number of firms and consequently the fixed costs, they are always welfare improving. In fact, the optimum number of varieties in every sector would be trivially equal to one in this case. Moreover, since product market regulations increase income when taste for variety is ruled out, they would also increase the relative size of the service employment share. Hence, in the $\frac{1}{1-\sigma}<\xi<0$ region, the effects of regulations on welfare and the services labor share are ambiguous, depending on the relative size of the fixed costs of production $\left(\psi^{r}\right)$ and stringency of product market regulations $(\kappa)$.

Sensitivity analysis with respect to $\xi$ is reported in Figures 6 and 7. Starting from $\xi=\frac{1}{1-\sigma}$ and $\kappa=0$, taste for variety and the stringency of product market regulations are increased progressively, comparing welfare and the service employment share share always with respect to the free entry case.

The service employment share shows a similar pattern to welfare when the stringency of regulations and taste for variety change. For sufficiently small $\kappa$ and enough dislike of variety, product market regulations actually increase income, raising welfare and the service employment share with respect to the free entry case. However, the effect of product market regulations on welfare anticipates the outcome regarding the service sector. Thus, a welfare reduction in the presence of economy-wide product market regulations is a sufficient condition for a reduction in the service employment share.

\section{Conclusions}

The service sector is the main engine of employment creation in developed economies. In spite of this wide-spread phenomenon, the dynamism of innovative service firms differs considerably across countries, and the lack of services jobs might be one of the sources of poor employment performance in some European countries.

I have shown that product market regulations that raise barriers to entry interact with the sources of structural change obstructing the development of sectors with income elastic demand, within a fairly standard general equilibrium model. Thus, stringent product market regulations hinder employment creation in the service sector. Sensitivity analysis shows that these results are robust to different degrees of taste for variety in preferences. If product market regulations are welfare decreasing, they also reduce the share of service employment. A preliminary examination of the data, extended in Messina (2002), shows that countries with more stringent product market regulations have lower service employment shares even after controlling for GDP per capita, supporting the 
theoretical findings.

The paper additionally suggests a supply-side rationale for the cross-country negative association between product market regulations and employment rates previously found in the literature. These institutions, by increasing rents and service prices might favor home production of services against market purchase, reducing labor supply.

These results suggest that de-regulating product markets in those economies and sectors where regulation proves obsolete might help employment creation and labor market participation. However, product market regulations are exogenous in the model. A welfare analysis in which product market regulations are endogenous is needed before drawing policy recommendations. Thus, this constitute the main line for further research. 


\section{References}

[1] Baumol, William (1967). Macroeconomics of Unbalanced Growth: the Anatomy of Urban Crisis. American Economic Review 57(4): 415-26.

[2] Bergstrand, Jeffrey H. (1991). Structural Determinants of Real Exchange Rates and National Price Levels. American Economic Review 81: 325-34.

[3] Bertrand, Marianne and Francis Kramarz (2002), Does Entry Regulation Hinder Job Creation? Evidence from the French Retail Industry. Quarterly Journal of Economics 67(4): 1369-1414.

[4] Blanchard, Olivier and Francesco Giavazzi (2002). Macroeconomic Effects of Regulation and Deregulation in Goods and labor Markets. Mimeo.

[5] Blanchard, Olivier and Nabuhiro Kiyotaki (1987). Monopolistic Competition and the Effects of Aggregate Demand. American Economic Review 77(4): 647-66.

[6] Broadberry, Stephen (1998). How did the United States and Germany Overtake Britain? A Sectoral Analysis of Comparative Productivity Levels, 1870-1990. in Historical Benchmark Comparisons of Output and Productivity. ed. Clara Eugenia Núñez, 17-29. Sevilla: Secretariado de Publicaciones de la Universidad de Sevilla.

[7] Brunello, Giorgio (1993). Markups in the labor and Product Markets and the Relative Performance of Industry and Services: Italy 1951-90. Centre for Economic Policy Research 811.

[8] Chenery, Hollis, Sherman Robinson, and Moshe Syrquin (1986). Industrialization and Growth. Washington: Oxford University Press.

[9] Clark, Colin (1957). The conditions of economic progress. London: MacMillan.

[10] Costa, Dora (1994). Agricultural Decline and the Secular Rise in Male Retirement Rates. NBER Historical Working Paper 55.

[11] Diewert, W. E. and T. J. Wales (1995). Flexible Functional Forms and Tests of Homogeneous Separability. Journal of Econometrics 67: 259-302

[12] Dixit, Avinash, and Joseph Stiglitz (1977). Monopolistic Competition and Optimum Product Diversity. American Economic Review 67(3): 297-308.

[13] - (1975). Monopolistic Competition and Optimum Product Diversity. Working Paper 64. University of Warwick. 
[14] Echevarría, Cristina (1997). Changes in the Sectoral Composition Associated with Economic Growth. International Economic Review 38(2): 431-52.

[15] Falvey, Rodney E., and Norman Gemmell (1996). Are Services Income-Elastic? Some New Evidence. Review of Income and Wealth 42(3): 257-69.

[16] Freeman, Richard B., and Ronald Schettkat (2002). Marketization of Production and the US-Europe Employment Gap. NBER Working Paper 8797.

[17] - (2000). Low Wage Services: Interpreting the US-German Difference. NBER Working Paper 7611.

[18] Fonseca, Raquel, Paloma Lopez-García and Christopher Pissarides (2001) Entrepreneurship, start-up costs and employment. European Economic Review 45(4-6): 692-705

[19] Gordon, Robert J. (1997). In there a Trade-off Between Unemployment and Productivity Growth in Unemployment Policy. ed. de la Dehesa, G. and Snower, D. Cambridge UP.

[20] - (1996). Problems in the Measurement and Performance of Service Sector Productivity in the United States. NBER Working Paper 5519.

[21] Gouyette, Claudine, and Sergio Perelman (1997). Productivity Convergence in OECD Service Industries. Structural Change and Economic Dynamics 8: 279-95.

[22] Griliches, Zvi (1994). Productivity, R\&D, and the Data Constraint. American Economic Review 84(1): 1-23.

[23] Kongsamut, Piyabha, Sergio Rebelo and Danyang Xie (2001). Beyond Balanced Growth. Review of Economic Studies 68(4): 269-82.

[24] Kuznets, Simon. (1966), Modern Economic Growth . London: Yale University Press.

[25] Messina, Julián (2002). Service Employment and Product Market Regulations: Evidence from a Panel of OECD Countries. Mimeo

[26] Nicoletti, Giuseppe, Ralph Haffner, Stephen Nickell, Stefano Scarpetta and G. Zoega (2001). European Integration, Liberalization and labor Market Performance, in Giuseppe Bertola, Tito Boeri and Giuseppe Nicoletti (eds.) Welfare and Employment in a United Europe, MIT Press.

[27] OECD (2000) Employment in the Service Economy: a Reassessment. in Employment Outlook. Chapter 3. Paris. 
[28] — (1999). Employment Outlook. Paris: OECD.

[29] Oliveira, Joaquim, Stefano Scarpetta and Dirk Pilat (1996). Mark-up Pricing, Market Structure. OECD Economic Studies 27(2): 71-105. 


\section{European Central Bank working paper series}

For a complete list of Working Papers published by the ECB, please visit the ECB's website (http://www.ecb.int).

II 3 "Financial frictions and the monetary transmission mechanism: theory, evidence and policy implications” by C. Bean, J. Larsen and K. Nikolov, January 2002.

I 4 "Monetary transmission in the euro area: where do we stand?" by I. Angeloni, A. Kashyap, B. Mojon, D. Terlizzese, January 2002.

II5 "Monetary policy rules, macroeconomic stability and inflation: a view from the trenches" by A. Orphanides, December 2001 .

116 "Rent indices for housing in West Germany 1985 to 1998" by J. Hoffmann and C. Kurz., January 2002.

117 "Hedonic house prices without characteristics: the case of new multiunit housing" by O. Bover and P. Velilla, January 2002.

118 "Durable goods, price indexes and quality change: an application to automobile prices in Italy, 1988-1998” by G. M. Tomat, January 2002.

119 "Monetary policy and the stock market in the euro area" by N. Cassola and C. Morana, January 2002.

120 "Learning stability in economics with heterogenous agents" by S. Honkapohja and K. Mitra, January 2002.

121 "Natural rate doubts" by A. Beyer and R. E. A. Farmer, February 2002.

122 "New technologies and productivity growth in the euro area" by F. Vijselaar and R. Albers, February 2002.

123 "Analysing and combining multiple credit assessments of financial institutions" by $\mathrm{E}$. Tabakis and A. Vinci, February 2002.

124 "Monetary policy, expectations and commitment" by G. W. Evans and S. Honkapohja, February 2002.

125 “Duration, volume and volatility impact of trades” by S. Manganelli, February 2002.

126 "Optimal contracts in a dynamic costly state verification model" by C. Monnet and E. Quintin, February 2002.

127 "Performance of monetary policy with internal central bank forecasting" by S. Honkapohja and K. Mitra, February 2002.

128 "Openness, imperfect exchange rate pass-through and monetary policy" by F. Smets and R. Wouters, February 2002. 
129 "Non-standard central bank loss functions, skewed risks, and certainty equivalence" by A. al-Nowaihi and L. Stracca, March 2002.

130 "Harmonized indexes of consumer prices: their conceptual foundations" by E. Diewert, March 2002.

|3| "Measurement bias in the HICP: what do we know, and what do we need to know?" by M. A. Wynne and D. Rodríguez-Palenzuela, March 2002.

132 "Inflation dynamics and dual inflation in accession countries: a "new Keynesian" perspective” by O. Arratibel, D. Rodríguez-Palenzuela and C. Thimann, March 2002.

133 "Can confidence indicators be useful to predict short term real GDP growth?" by A. Mourougane and M. Roma, March 2002.

I 34 "The cost of private transportation in the Netherlands, 1992-1999" by B. Bode and J. Van Dalen, March 2002.

135 "The optimal mix of taxes on money, consumption and income" by F. De Fiore and P. Teles, April 2002.

I36 "Retail bank interest rate pass-through: the new evidence at the euro area level" by G. de Bondt, April 2002.

137 "Equilibrium bidding in the eurosystem's open market operations" by U. Bindseil, April 2002.

138 "New" views on the optimum currency area theory: what is EMU telling us?" by F. P. Mongelli, April 2002.

139 “On currency crises and contagion” by M. Fratzscher, April 2002.

140 "Price setting and the steady-state effects of inflation" by M. Casares, May 2002.

14I “Asset prices and fiscal balances” by F. Eschenbach and L. Schuknecht, May 2002.

142 "Modelling the daily banknotes in circulation in the context of the liquidity management of the European Central Bank”, by A. Cabrero, G. Camba-Mendez, A. Hirsch and F. Nieto, May 2002.

143 “A non-parametric method for valuing new goods", by I. Crawford, May 2002.

I 44 "A failure in the measurement of inflation: results from a hedonic and matched experiment using scanner data", by M. Silver and S. Heravi, May 2002.

145 "Towards a new early warning system of financial crises", by M. Fratzscher and M. Bussiere, May 2002.

146 “Competition and stability - what's special about banking?”, by E. Carletti and P. Hartmann, May 2002. 
147 "Time-to-build approach in a sticky price, stricky wage optimizing monetary model, by M. Casares, May 2002.

148 "The functional form of yield curves" by V. Brousseau, May 2002.

149 "The Spanish block of the ESCB-multi-country model" by A. Estrada and A. Willman, May 2002.

150 "Equity and bond market signals as leading indicators of bank fragility" by R. Gropp, J. Vesala and G. Vulpes, June 2002.

15I "G-7 inflation forecasts" by F. Canova, June 2002.

152 "Short-term monitoring of fiscal policy discipline" by G. Camba-Mendez and A. Lamo, June 2002.

153 "Euro area production function and potential output: a supply side system approach" by A. Willman, June 2002.

154 "The euro bloc, the dollar bloc and the yen bloc: how much monetary policy independence can exchange rate flexibility buy in an interdependent world?" by M. Fratzscher, June 2002.

155 "Youth unemployment in the OECD: demographic shifts, labour market institutions, and macroeconomic shocks" by J. F. Jimeno and D. Rodriguez-Palenzuela, June 2002.

156 "Identifying endogenous fiscal policy rules for macroeconomic models" by J. J. Perez, and P. Hiebert, July 2002.

157 "Bidding and performance in repo auctions: evidence from ECB open market operations" by K. G. Nyborg, U. Bindseil and I. A. Strebulaev, July 2002.

158 "Quantifying Embodied Technological Change" by P. Sakellaris and D. J. Wilson, July 2002.

159 “Optimal public money” by C. Monnet, July 2002.

160 "Model uncertainty and the equilibrium value of the real effective euro exchange rate" by C. Detken, A. Dieppe, J. Henry, C. Marin and F. Smets, July 2002.

161 "The optimal allocation of risks under prospect theory" by L. Stracca, July 2002.

162 "Public debt asymmetries: the effect on taxes and spending in the European Union" by S. Krogstrup, August 2002.

163 "The rationality of consumers' inflation expectations: survey-based evidence for the euro area" by M. Forsells and G. Kenny, August 2002.

164 "Euro area corporate debt securities market: first empirical evidence" by G. de Bondt, August 2002. 
165 "The industry effects of monetary policy in the euro area" by G. Peersman and F. Smets, August 2002.

166 "Monetary and fiscal policy interactions in a micro-founded model of a monetary union" by R. M.W.J. Beetsma and H. Jensen, August 2002.

167 "Identifying the effects of monetary policy shocks on exchange rates using high frequency data" by J. Faust, J.H. Rogers, E. Swanson and J.H. Wright, August 2002.

168 "Estimating the effects of fiscal policy in OECD countries" by R. Perotti, August 2002.

169 “Modeling model uncertainty” by A. Onatski and N. Williams, August 2002.

170 "What measure of inflation should a central bank target?" by G. Mankiw and R. Reis, August 2002.

I7I "An estimated stochastic dynamic general equilibrium model of the euro area" by F. Smets and R. Wouters, August 2002.

172 "Constructing quality-adjusted price indices: a comparison of hedonic and discrete choice models" by N. Jonker, September 2002.

173 "Openness and equilibrium determinacy under interest rate rules" by F. de Fiore and Z. Liu, September 2002.

174 "International monetary policy coordination and financial market integration" by A. Sutherland, September 2002.

175 "Monetary policy and the financial accelerator in a monetary union" by S. Gilchrist, J.O. Hairault and H. Kempf, September 2002.

176 "Macroeconomics of international price discrimination" by G. Corsetti and L. Dedola, September 2002.

177 "A theory of the currency denomination of international trade" by P. Bacchetta and E. van Wincoop, September 2002.

178 "Inflation persistence and optimal monetary policy in the euro area" by P. Benigno and J.D. López-Salido, September 2002.

179 "Optimal monetary policy with durable and non-durable goods" by C.J. Erceg and A.T. Levin, September 2002.

180 "Regional inflation in a currency union: fiscal policy vs. fundamentals" by $M$. Duarte and A.L. Wolman, September 2002.

18I "Inflation dynamics and international linkages: a model of the United States, the euro area and Japan” by G. Coenen and V. Wieland, September 2002.

182 "The information content of real-time output gap estimates, an application to the euro area” by G. Rünstler, September 2002. 
183 "Monetary policy in a world with different financial systems" by E. Faia, October 2002.

184 "Efficient pricing of large value interbank payment systems" by C. Holthausen and J.-C. Rochet, October 2002.

185 "European integration: what lessons for other regions? The case of Latin America" by E. Dorrucci, S. Firpo, M. Fratzscher and F. P. Mongelli, October 2002.

186 "Using money market rates to assess the alternatives of fixed vs. variable rate tenders: the lesson from 1989-1998 data for Germany” by M. Manna, October 2002.

187 “A fiscal theory of sovereign risk” by M. Uribe, October 2002.

188 "Should central banks really be flexible?" by H. P. Grüner, October 2002.

189 "Debt reduction and automatic stabilisation" by P. Hiebert, J. J. Pérez and M. Rostagno, October 2002.

190 "Monetary policy and the zero bound to interest rates: a review" by T. Yates, October 2002.

191 "The fiscal costs of financial instability revisited" by L. Schuknecht and F. Eschenbach, November 2002.

192 "Is the European Central Bank (and the United States Federal Reserve) predictable?" by G. Perez-Quiros and J. Sicilia, November 2002.

193 "Sustainability of public finances and automatic stabilisation under a rule of budgetary discipline” by J. Marín, November 2002.

194 "Sensitivity analysis of volatility: a new tool for risk management" by S. Manganelli, V. Ceci and W. Vecchiato, November 2002.

195 “In-sample or out-of-sample tests of predictability: which one should we use?" by A. Inoue and L. Kilian, November 2002.

196 "Bootstrapping autoregressions with conditional heteroskedasticity of unknown form" by S. Gonçalves and L. Kilian, November 2002.

197 "A model of the Eurosystem's operational framework for monetary policy implementation" by C. Ewerhart, November 2002.

198 "Extracting risk neutral probability densities by fitting implied volatility smiles: some methodological points and an application to the 3M Euribor futures option prices" by A. B. Andersen and T. Wagener, December 2002.

199 "Time variation in the tail behaviour of bund futures returns" by T. Werner and C. Upper, December 2002. 
200 "Interdependence between the euro area and the US: what role for EMU?" by M. Ehrmann and M. Fratzscher, December 2002.

20 I "Euro area inflation persistence" by N. Batini, December 2002.

202 "Aggregate loans to the euro area private sector" by A. Calza, M. Manrique and J. Sousa, January 2003.

203 "Myopic loss aversion, disappointment aversion, and the equity premium puzzle" by D. Fielding and L. Stracca, January 2003.

204 "Asymmetric dynamics in the correlations of global equity and bond returns" by L. Cappiello, R.F. Engle and K. Sheppard, January 2003.

205 "Real exchange rate in an inter-temporal n-country-model with incomplete markets" by B. Mercereau, January 2003.

206 "Empirical estimates of reaction functions for the euro area" by D. Gerdesmeier and B. Roffia, January 2003.

207 “A comprehensive model on the euro overnight rate” by F. R. Würtz, January 2003.

208 "Do demographic changes affect risk premiums? Evidence from international data" by A. Ang and A. Maddaloni, January 2003.

209 “A framework for collateral risk control determination” by D. Cossin, Z. Huang, D. Aunon-Nerin and F. González, January 2003.

210 "Anticipated Ramsey reforms and the uniform taxation principle: the role of international financial markets” by S. Schmitt-Grohé and M. Uribe, January 2003.

211 "Self-control and savings" by P. Michel and J.P. Vidal, January 2003.

212 "Modelling the implied probability of stock market movements" by E. Glatzer and M. Scheicher, January 2003.

213 “Aggregation and euro area Phillips curves" by S. Fabiani and J. Morgan, February 2003.

214 "On the selection of forecasting models" by A. Inoue and L. Kilian, February 2003.

215 "Budget institutions and fiscal performance in Central and Eastern European countries" by H. Gleich, February 2003.

216 "The admission of accession countries to an enlarged monetary union: a tentative assessment” by M. Ca' Zorzi and R. A. De Santis, February 2003.

217 "The role of product market regulations in the process of structural change" by J. Messina, March 2003. 